\title{
MURILO RUBIÃO: PIROTÉCNICO MÁGICO DAS PALAVRAS
}

\begin{abstract}
JIRO TAKAHASHI
Mestre em Linguística Semiótica - pela Faculdade de Filosofia, Letras e

Ciências Humanas - USP (2010) Universidade de São Paulo (conceito CAPES 7). É graduado em em Letras pela

Universidade de São Paulo (1975) e licenciado em Letras pela Universidade de São Paulo (1976). Atualmente é docente do Centro Universitário FAM. Tem 50 anos de atuação em direção editorial nas editoras Ática - foi criador de várias coleções literárias, como a Vaga-lume, a Para Gostar de Ler e a Nosso Tempo -, Nova Fronteira, Editora do Brasil, Grupo Ediouro e Grupo Rocco. Atualmente é coordenador literário de Zapt Editora e diretor executivo da Editora Nova Aguilar, respondendo pela edição de Obras Completas

de clássicos nacionais e internacionais.
\end{abstract}

1973 foi um ano especial para mim. Neste ano eu conheci pessoalmente Murilo Rubião, que tinha publicado sua primeira edição de Ex-mágico, em setembro de 1947, exatamente dois meses antes do meu nascimento. Esse livro foi publicado pela pequena Editora Universal, a mesma que havia lançado também os contos de Sagarana, de outro promissor escritor, Guimarães Rosa.

Antes de ler seus contos, havia ouvido falar dele pelo professor Antonio Candido, que lembrava ter sido companheiro no famoso Congresso Brasileiro de Escritores, em janeiro de 1945, importante evento que viria contribuir para o fim do Estado Novo; pelo professor Davi Arrigucci Jr., de quem eu tinha sido aluno em um curso sobre literatura fantástica; e pelo professor Jorge Schwartz, que preparava sua dissertação de mestrado sobre Murilo Rubião, mais tarde publicada com o título: Murilo Rubião: A Poética do Uroboro.

Com esse consistente arcabouço crítico, pude fazer uma leitura mais atenta e madura do que se a tivesse feito com toda a insegurança normal de um estudante de letras. Pude compreender melhor, com grande entusiasmo, todos seus contos publicados até então.

No ano de 1973, estava sendo lançada, pela Ática, a Série Vaga-lume, destinada a jovens estudantes das séries finais do antigo 1으 grau. Nessa editora, estávamos preparando outra série, destinada ao ensino médio e universitário. 
A ideia era fazer a prospecção de autores contemporâneos com respaldo crítico e com temática que dialogasse com as inquietações da juventude da época. Foi assim que nasceu a Coleção Nosso Tempo e insisti muito, dentro da Ática, para que a série fosse aberta com Murilo Rubião. Para uma coleção pioneira nada melhor do que um autor pioneiro.

Telefonei para a redação de Minas Gerais, que publicava o Suplemento Literário, uma maravilhosa criação de Murilo. Fiz a proposta de edição de seus contos, com uma tiragem de 30 mil exemplares, o que iria permitir um baixo preço para os leitores.

No entusiasmo dos meus 25 anos, eu me apressei em marcar um encontro pessoal com o Murilo em Belo Horizonte. Eu me apresentei na redação do Suplemento Literário, conversei rapidamente com o Murilo porque era o horário normal de trabalho. Ele pediu que eu passasse no final do dia para conversarmos mais tranquilamente em um bar do famoso Edifício Maletta, próximo do jornal.

À noitinha, lá fomos o Murilo e eu ao Bar Lua Nova, que funcionava dentro do Maletta. Em uma mesa de canto, uma cadeira virada sobre a mesa. Era a mesa do Murilo, por onde ele passava diariamente antes de voltar para casa. Acho que morava na Rua do Ouro, onde o visitei algumas vezes. Eu me senti muito privilegiado quando me disseram que ele não costumava receber muita gente em casa.

Consegui convencê-lo a aceitar o risco da tiragem de 30 mil exemplares para a primeira edição de uma seleção de seus contos que ainda estávamos preparando. Assinado o contrato, começamos a produção e, na revisão das provas tipográficas, o Murilo fazia questão 
de acompanhar tudo linha a linha. Ele nunca se queixou de eventuais "correções" que a revisão apontava, mas ele próprio corrigia muito mais, a ponto de reescrever alguns contos. Chegou a reescrevê-los mudando até o foco narrativo. Ele me escrevia justificando a alteração de forma tão convincente que hoje penso que, se a editora tivesse guardado essa correspondência, poderia se tornar artigo teórico de teoria da narrativa, como o romancista britânico E. M. Foster fez com seu Aspectos do romance. Aliás, isso já foi observado por Jorge Schwartz no tópico "A filosofia da composição muriliana" de seu livro que já citei aqui.

Como o livro abriria uma nova coleção, tínhamos de pensar em um projeto gráfico para sustentar visualmente os novos livros que viriam na sequência. Elifas Andreato, grande artista gráfico, aceitou ser responsável pelo projeto, pela capa e pelas ilustrações que o livro teria. Ele ficou muito emocionado por estar ilustrando o livro de um autor que tinha publicado a primeira edição um ano depois de ele ter nascido. Fizemos uma pequena exposição das artes finais de seus desenhos no Palácio das Artes, na noite do lançamento do livro, com a presença de um emocionado Elifas.

No lançamento do livro, o Murilo me confidenciou que havia dormido com o livro debaixo de seu travesseiro. Outra confidência dele, em outra ocasião, foi que ele copiava, inteiramente à mão, com sua caneta, alguns romances de Machado de Assis, principalmente - Quincas Borba. Quando eu questionava esse hábito totalmente espantoso e inusitado, ele dizia candidamente que, com isso, sua mão passaria pela experiência de escrever aqueles parágrafos e provavelmente teria uma "memória" deles. 
Mais tarde, eu teria ainda o privilégio de lançar outra seleção de seus contos, com o título $A$ casa do girassol vermelho, em 1978, também pela Ática. Mais um sucesso de crítica e de público. No ano seguinte, uma grande alegria para o Murilo: publicação nos Estados Unidos de The Ex-Magician and other stories (Harper and Row), em tradução de Thomas Colchie, que se tornara seu agente literário e de tantos outros autores latino-americanos. Alguns anos depois, em 1981, seria publicado Der Feuwerker Zacharias, na Alemanha, pela prestigiosa editora Suhrkamp.

Quando ficou doente, algumas vezes ainda o visitei. Na última vez, ele tinha recebido a liberação de seu médico para sair de sua dieta muito restrita. E sugeriu que fôssemos mais uma vez ao velho restaurante Alpino, onde estivéramos várias outras vezes. Então, foi a última.

Pessoalmente, fantasio que, no dia 16 de setembro de 1991, da janela, ele deve ter visto que a paisagem perdia a cor. Então, deve ter pensado, como o seu personagem Zacarias: sem cor, a vida não teria mais sentido. 